\title{
A First Step Towards Service-Dominant Logic as a New APPROACH TO OVERCOME CHALLENGES IN BUSINESS INTELLIGENCE
}

\author{
Pamela Clavier and Johan van Loggerenberg
}

Department of Informatics, University of Pretoria

\author{
Hugo Lotriet
}

School of Computing, University of South Africa

Accepted: October 2013

\begin{abstract}
High expectations are set for Business Intelligence (BI), yet it fails to consistently deliver accordingly: there are numerous reports of $\mathrm{BI}$ challenges and failures. Existing approaches to address $\mathrm{BI}$ challenges are largely found to be ineffective, highlighting the need for a new approach.

This paper examines how $\mathrm{BI}$ is perceived or understood and establishes that, firstly, $\mathrm{BI}$ is inherently grounded in Goods-Dominant (G-D) logic and secondly, that this can be linked to the challenges that are experienced within BI. A recommendation is made for a shift to Service-Dominant (S-D) logic as a new avenue of exploration to assist in overcoming Bl's prevailing challenges. Identifying the inherent G-D logic in $\mathrm{BI}$ provides the first step necessary in making this shift.

Research findings are based on an interpretive case study of a South African Banking institution as well as a literature review.
\end{abstract}

Key words: business Intelligence, service-dominant logic, goods-dominant logic, business intelligence challenges

JEL: O32, M15

1

\section{Introduction}

This paper examines Business Intelligence (BI) - a specialised Information System (IS) (Berstein, Grosof, \& Provost, 2011) - at an abstract level, as a series of exchange activities performed with the ultimate purpose of providing actionable information and/or intelligence for use in decision-making (Hočevar \& Jaklič, 2010). BI is contextualized in terms of exchange because it is identified that there are various exchange activities that take place within the BI environment throughout the BI process, i.e. processes to transform raw data into useful information for insights and decisionmaking (Duan \& Da $\mathrm{Xu}, 2012$ ). Understanding $\mathrm{BI}$ as an exchange process offers opportunities to understand the various relationships (e.g. BI customer and BI provider), their interactions and their perceptions and understanding of the end-to-end flow that takes place within a BI environment from when data is sourced until when it is used (in another form, e.g. intelligence). This is complemented by application of Service-Dominant (S-D) logic as a lens through which to view the BI exchange process.

S-D logic is a philosophical lens through which economic and social exchange processes can be viewed (Vargo, 2011), including exchange processes that take place within the BI environment. S-D Logic questions traditional views of the exchange of goods and service (Kowalkowski \& Ballantyne, 2009), referring to these views as "G-D logic" (Lusch, Vargo \& Wessels, 2008). S-D logic urges for a shift from G-D logic; establishing that G-D logic is an inadequate logic that fails to benefit today's exchange process (Vargo \& Lusch, 2004a). While S-D logic cannot be proved or disproved (Williams \& Aitken, 2011), it can be demonstrated as a viable approach. Various research efforts across disciplines - e.g. Information and communication technology (ICT), economics and marketing show how G-D logic fails to serve exchange optimally (Vargo \& Lusch, 2004a), suggesting $\mathrm{S}-\mathrm{D}$ logic as a more viable approach. 
This paper highlights the inadequacies of G$\mathrm{D}$ logic that are apparent within the BI environment, linking these to how BI is perceived or understood as well as to the challenges that are experienced within BI. A perception results in a set of beliefs through which the world is interpreted or interacted with, which results in challenges or opportunities that are created within a specific situation and context (Heylighen, 2000). In this paper, the way that BI is perceived or understood is explored in terms of, firstly, perceptions of BI that emerge from how BI is defined and secondly, the beliefs about BI that emerge in the research material. BI challenges are then examined as possible results of the perceptions and beliefs through which the world of BI is interpreted and interacted with. This provides a broader view under which BI exchange - and the challenges experienced therein - may be understood.

Findings are based on a literature review including extensive analysis of BI definitions and a case study. The case study was conducted over a three and a half year period at one of South Africa's largest banks, referred to as Fortune Bank (FB) to protect its anonymity. FB and its $\mathrm{BI}$ vendors were involved in the case study.

This paper's principal contribution is identification of BI's inherent G-D logic, providing the necessary first step towards exploring S-D logic as a new approach to overcome BI's prevailing challenges. Research on how BI is typically understood and the relationship between this understanding and the challenges experienced in BI are further contributions. Finally, another contribution is the unique application of S-D logic to BI within the realm of Information Systems (IS) research.

This paper's research questions are:

1) How is BI understood/perceived?

2) Is the way $B I$ is understood grounded in G-D or S-D logic?

3) Can BI challenges be linked to G-D logic or the way BI is understood?

2

\section{Literature review}

\subsection{Literature review methodology}

A systematic literature review was conducted iteratively over four years, with the bulk of the review being completed in 2012. Steps based on Vom Brocke, Simons, Niehaves, Riemer, Cleven and Plattfaut (2009) were executed to advance knowledge on BI and S-D logic and to identify gaps in the existing body of knowledge presenting research opportunities (Henning, Van Rensburg \& Smit, 2004). Steps included: 1) define scope 2) conceptualise the topic 3) gather literature 4) analyse and synthesise literature 5) compile literature review. The literature review was then used as a foundation for the case study, which is detailed in Section 3 of this paper. Literature from South African and international academic and practitioner sources was reviewed to gain representative coverage of current and historical as well as conceptual and practical research on BI and SD logic.

Webster and Watson's (2002) guidelines to identify research material by sourcing material cited in primary material (backwards) and material that cites the primary material (forwards) were followed to gather literature. Findings were summarised and categorised using keywords to facilitate identification of relationships, trends and discord in gathered material and to facilitate comparison with case study findings.

To analyse literature on BI perceptions, the approach taken by Payne and Frow (2005) was applied. Payne and Frow analyse Customer relationship management (CRM) definitions to understand perceptions of CRM. This entailed collation of BI definitions followed by analysis thereof. 70 BI definitions - reflective of academic/ practitioner and South African/global literature spanning from 1986 to 2012 - were selected for analysis based on the definition's relevance and the source's academic or professional credibility. Analysis was performed by summarising and categorising keywords to flag patterns and discord that emerged in the data that was gathered. In addition to Payne and Frow's approach, discourse on BI definitions (e.g. from Ackerman, 2005; Herschel, 2011; Pirttimäki, 2007) was analysed in the same way.

The literature review as a whole was refreshed in 2013 to confirm current relevance. The 2013 review was performed through research of a representative sample rather than a repeat of previous in-depth reviews. 


\subsection{BI expectations versus BI success}

$\mathrm{BI}$ is consistently ranked as a top business priority in global Gartner surveys (Hočevar \& Jaklič, 2010) and is identified as the most essential technology for the organisation to purchase (Chuah \& Wong, 2011) resulting from the benefits the organisation is described to gain after purchasing a BI solution. Nearly 90 per cent of organisations across the world have implemented a BI capability, with BI seeing a global spend of around USD $\$ 60$ billion annually (Coulonval, Curitz \& Finkelstein, 2010). South African banks, in particular, are reported to have invested significantly in BI after realising its importance for strategic and tactical decision-making (Vanmare, 2006).

This sustained intense investment in BI should indicate that investors (organisations) are receiving benefits from their investment. Instead, there are reports that BI Return on Investment (ROI) is difficult to measure (Vanmare, 2006) and still further reports of major BI challenges and failures. In South Africa, financial institutions struggle to realise value from their BI investments due to challenges in unlocking actionable BI for decision-making (Ackerman, 2005). In fact, over 50 per cent of BI projects are reported to fail worldwide (Atre, 2011; LaValle, Hopkins, Lesser, Shockley \& Kruschwitz, 2010).

\subsection{BI challenges and existing approaches to overcome BI challenges}

The word "challenge" may be understood as: a new or difficult task that tests ability and skill (e.g. "schools must meet the challenge of new technology", i.e. "deal with it successfully") or; to question a statement/action or; an invitation to enter a competition, fight, etc. (Hornby, 2005). The understanding presented in the first definition is applicable to BI challenges as discussed in this paper. Furthermore, a literature review of BI challenges (Clavier, Lotriet \& Van Loggerenberg, 2012) establishes that BI challenges are seen as difficulties experienced within or impacting on the BI environment that, if overcome, contribute towards achieving successful use of BI.

Previous research (Clavier, 2012) discusses and categorises BI challenges and existing attempts to resolve them in a literature review.
To build on rather than duplicate, only key findings are now repeated.

Key findings on BI challenges include: firstly, as a specialised type of IS (Berstein et al., 2011), BI faces many of the same challenges that ISs do (e.g. absence of adequate sponsorship (Hočevar \& Jaklič, 2010), in addition to specific $\mathrm{BI}$ challenges (e.g. BI is an ill-defined discipline in an ambiguous environment (Ackerman, 2005; Pirttimäki, 2007; Herschel, 2011); secondly, while there are many ways in which BI challenges may be categorised, clear categories emerge consistently in academic and practitioner literature, namely: use, data, integration, alignment, personnel and skills, and sponsorship.

While the importance of all these BI challenge categories is recognised, this paper focuses on "use" and "data" to enable greater depth within the bounds of the paper's space constraints. These are incorporated in Table 3 to enable a comparison of literature and case study findings. "Use" and "data" are selected as, during the literature and case study review, it was discovered that much overlap exists between these categories, added to which, the case study resulted in a rich data set on these specific categories. It is the intention to followup on this paper in the future with subsequent papers that discuss the other challenge categories in similar depth.

Key findings on existing approaches to resolve BI challenges are that they: largely fail to consistently and comprehensively resolve BI challenges; do not focus on addressing BI's prevailing challenges as they are not directly associated with challenges; tend to focus on BI up to the end of implementation of an IT solution - neglecting use of BI or the full data life cycle; are typically restricted to the environmental and organisational parameters of designing a BI system.

These key findings highlight the need for a new approach that overcomes existing approaches' limitations. In response, this paper recommends taking a step back to first understand BI conceptually and then examining findings gained from this understanding using G-D and S-D logic. To understand BI conceptually, this paper examines how BI is perceived or understood, examining BI definitions and discourse on BI definitions. G-D and S-D logic are then applied. 
Literature review sections that follow provide context for G-D and S-D logic, position BI in terms of G-D and S-D logic and then present literature review findings on how BI is perceived.

\subsection{G-D and S-D logic}

G-D and S-D logic fit within the multidisciplinary research area of service science (Maglio \& Spohrer, 2008). Service Science is supported by S-D logic as a philosophical foundation, service systems theory as a theoretical foundation and practical developments such as service management and service computing among others (Maglio \& Spohrer, 2008). Vargo and Lusch's ground-breaking SD logic paper (2004a) put S-D logic in the spotlight, attracting much dialogue (Randall, 2007). Since then, there have been at least six S-D logic focused conferences, twelve S-D logic special issues or journal sections, hundreds of papers and presentations grounded in S-D logic and thousands of citations and cross citations to S-D logic related work - from various disciplines and countries across the world (Vargo, 2011; Williams \& Aitken, 2011). This paper therefore unashamedly uses what has already been established in the philosophy of S-D logic as a point of departure. A brief introduction is now provided for the purpose of context for this paper.

G-D and S-D logic are lenses or philosophies to view "exchange" (Vargo, 2011). Exchange is the act of giving and receiving (Hornby, 2005), which also applies to economic or social acts of giving (e.g. selling, leasing) and receiving (e.g. buying, renting). Exchange centres on relationships and interactions (Schultz \& Gnoth, 2008) to give provider and customer (and others involved) access to resources that provide them with benefit (Chandler \& Vargo, 2011).

The traditional view of exchange - G-D logic - promotes value-in-exchange and a separation of producer and consumer (Gummesson, 1995; Vargo \& Lusch, 2006), it focuses on the product (including its embedded features), means, producer and production (Vargo \& Lusch, 2006; Edvardsson, Ng, Zhi Min, Firth \& Yi, 2011). G-D logic typically sees exchange as a linear series of activities of sourcing, producing and distributing tangible saleable goods, designed and built by a producer who embeds the goods with utility and value during the production and distribution processes with a consumer in mind Vargo \& Lusch, 2004a; Edvardsson et al., 2011). In cases where no tangible product is exchanged, e.g. having a haircut, attending a class or consulting with a lawyer, G-D logic refers to a service, where service is seen as unproductive and, although not useless, as failing to contribute to the creation of wealth (Vargo, 2011; Kowalkowski \& Ballantyne, 2009). Further examples of G-D logic characteristics are tabulated in Table 3, where they are used to show the inherent G-D logic that can be observed in BI.

It may be argued that G-D logic is now a thing of the past as a result of postindustrialisation and the rise of the service sector (World Bank, 2013). However, S-D logic is significantly broader than the traditional view of service (Vargo \& Lusch, 2008) and, as will be demonstrated in this paper, G-D logic is not a thing of the past; there are profound implications of a G-D logic based mindset that can be seen within BI today (Clavier, 2012).

S-D Logic questions G-D logic's traditional views of service and recognises traditional service as "direct service" and goods as "indirect service" (Kowalkowski \& Ballantyne, 2009). It recognises the service that is inherent in goods and, conversely to G-D logic, defines goods in terms of service. Service is seen as the application of competences (skills and knowledge) through deeds, processes and performances for the benefit of another entity or the entity itself (Vargo \& Lusch, 2004b). Skills and knowledge are seen to be embedded in goods, where goods are the transport mechanism for distributing these skills and knowledge (Vargo \& Lusch, 2004a).

S-D logic's central tenet is that service is the basis of all exchange (Vargo \& Lusch, 2004a). It's primary definition being that service is the application of competences for the benefit of another entity (Vargo \& Lusch, 2004a). It sees exchange (including the exchange of goods) as a flow of service where customer and provider collaboratively interact with each other and other economic and social actors to co-create value, which is phenomenologically measured by the customer (and not upfront by the provider) (Maglio \& Spohrer, 2013). S-D logic represents a shift from G-D logic to a focus on value in use, the customer, 
the process, the intangible, the relationship and the doing (Lusch \& Vargo, 2006).

\section{5 $\mathrm{BI}$ as an exchange process in context of S-D logic}

Exchange (and the lenses through which it is viewed) is directly applicable to organisations, employees, suppliers, customers and other stakeholders (Schultz \& Gnoth, 2008). Extending this proposition, consider BI as an exchange process: essentially BI consists of a broad series of exchange activities performed by and using various resources (e.g. data, systems, various actors such as IT, business, etc.) that are integrated and engage to ultimately provide actionable information and/or intelligence for use in decision-making (Hočevar \& Jaklič, 2010). For example, at an abstract level, the various exchange processes that need to take place to transform raw data into useful information for insights and decision-making (Duan \& Da Xu, 2012). The BI provider processes data and information, delivering this (by means of implementing e.g. a BI report, tool or solution) to the BI customer, who is then expected to use what is delivered to analyse and gain insights and intelligence. Understanding $\mathrm{BI}$ as an exchange process offers opportunities to understand the various relationships (e.g. BI customer and BI provider), their interactions and their perceptions and understanding of the end-to-end flow that takes place from when data is sourced until when it is used (in another form, e.g. intelligence).

S-D logic is especially useful for complex and adaptive environments (Lusch \& Webster, 2011) such as BI. S-D logic offers a multidimensional view of all of BI's role players, resources, relationships and integration points.
It views all social and economic actors as resource integrators (Vargo \& Lusch, 2008), broadening the view that $\mathrm{BI}$ is all about technology (Herschel, 2011). Not only can BI be seen in the full context of its end-to-end flow of activities, but use of S-D logic offers the opportunity to understand the detail of the relationships, from the customer and relationship viewpoint, in context of the use or value that can potentially result from the interaction (Vargo \& Lusch, 2008).

\subsection{How BI is understood: perceptions of BI}

As described in the literature review methodology above, BI definitions and discourse on BI definitions were analysed to understand how $\mathrm{BI}$ is perceived (i.e. understood or comprehended) by academics and practitioners. Such understanding leads to improved understanding of how to overcome BI's challenges - as per Heylighen's (2000) research. Heylighen (2000) establishes that a perception results in a set of beliefs through which the world is interpreted or interacted with, which results in challenges or opportunities that are created within a specific situation and context.

Four common perceptions consistently emerged in the literature review, described below in Table 1 and shown again in Table 3. While this list reflects just one subjective view that is based on the reality of the researcher and of the authors whose definitions and discourse were analysed, it serves its purpose as a basis for understanding how BI is perceived. Examples of other perceptions that may be used to categorise BI are: strategic/ tactical; internal/external; detailed/broad; integrated/ specific; past/ future; etc. (Pirttimäki, 2007).

Table 1

Perceptions of $\mathrm{BI}$

\begin{tabular}{l}
\hline Common perceptions: $\mathrm{BI}$ is ... \\
$\begin{array}{l}\text { A technology that consists of one/a combination of components such as hardware, software, databases, etc. } \\
\text { controlled, managed and governed by technical practices and methodologies }\end{array}$ \\
\hline $\begin{array}{l}\text { A process that consists of activities to gather, process, analyse and distribute information, transforming data into } \\
\text { information into intelligence. It refers to the "means" of BI }\end{array}$ \\
\hline $\begin{array}{l}\text { A product, output, result or outcome representing meaningful and useful information that is actionable. It may be the } \\
\text { outcome of the BI or another process (e.g. intelligence from an employee's own personal knowledge) }\end{array}$ \\
\hline The capability to perform the BI process or to access and analyse information \\
\hline
\end{tabular}

Table 3, which follows in the Discussion section of this paper to enable comparison of literature review and case study findings without duplication thereof, lists each perception with: 1) typical beliefs, 2) associated challenges and 3) inherent G-D logic characteristics. 1, 2 and 3 were also 
identified in the literature review and case study. As with the perceptions, Table 3 reflects a subjective view that may be re-organised by another but serves its purpose as a basis for organising and synthesising the key findings of this research. Typical beliefs and associated challenges are linked to BI perception based on the principal focus of the belief/ challenge and whether this can be logically categorised as technology, process, product or capability.

Table 3's associated challenges (2) and inherent G-D logic characteristics (3) are introduced in literature review sections above. It is now necessary to introduce Table 3's typical beliefs (3). "Belief" is linked to perception based on Heylighen's research, which identifies that particular beliefs (i.e. opinions or convictions) result from understanding (perceiving) something in a particular way. As an example, consider the belief that the earth is flat as a result of a particular understanding (perception) of astronomy. Further examples (aligned with this paper's topic) are reflected in Table 3.

3

\section{Case study methodology}

A three and a half year case study was conducted within one of Fortune Bank's BI departments to gain understanding of FB's perceptions of BI, the associated beliefs held about BI and its BI successes, failures and challenges. Data gathering was qualitative and interpretive. Techniques included observation, interviews and questionnaires. Questionnaire and interview questions are reflected in Table 2.

The researcher observed the BI environment, including BI initiatives (strategic and project) and BI operations, as a full time employee of the BI department. The researcher did this in various roles on core BI projects and operational work. This provided a comprehensive view of the BI Department's relationships and the behaviour between various human and technological entities through its BI processes, documentation and activities.

Semi-structured interviews were held with 14 senior staff members, each ranging between one to two hours in duration. Interviewees were selected based on involvement in a core BI initiative and ability to offer insight based on experience in BI or a related discipline (e.g. MIS, decision-support). Interviewees were involved as BI providers (from the BI department) or BI customers (e.g. users as clients of the BI department, employed in another of FB's departments).

At the time of the case study, FB was conducting a Request for Proposal (RFP) to identify a vendor to partner with them to assist them to move one of its BI departments up a few maturity levels to become a business intelligence competence centre (BICC). The RFP process was seen as a research opportunity to take advantage of, as the RFP responses provided a direct vendor perception of BI. FB identified vendors to distribute the RFP based on Gartner's 2008 BI magic quadrant diagram (Richardson, Schlegel, Hostmann \& McMurchy, 2009). The BI department's senior management team considered this to be representative of $\mathrm{BI}$ vendors active in the South African BI market. Eight out of 36 vendors responded to the RFP. The BI department considered this to be a good response based on the fact that not all of the vendors approached specialised directly in BI and many had a purely technology focus and were therefore unable to assist from an organisational design and culture point of view, which the RFP called for.

The following types of questions were asked:

Table 2

Questionnaire (Q) and Interview (I) Questions*

\begin{tabular}{|l|c|c|}
\hline Define your organisation's BI process. & $\mathbf{Q}$ & $\mathbf{I}$ \\
\hline How do you define the term BI? & $\checkmark$ & $\checkmark$ \\
\hline What do you see as the components of BI? & $\checkmark$ & $\checkmark$ \\
\hline What are the main deliverables of BI? & $\checkmark$ & $\checkmark$ \\
\hline How do you use BI? What is its purpose? & $\checkmark$ & $\checkmark$ \\
\hline What challenges or failures have you experienced in BI? & & $\checkmark$ \\
\hline What challenges or failures do you consider to be BI challenges or failures? & $\checkmark$ & $\checkmark$ \\
\hline What have you done to overcome the challenges? Did it work? & $\checkmark$ & $\checkmark$ \\
\hline
\end{tabular}

*Background questions aren't reflected. Only questions related to this paper are reflected, not all questions asked. 


\section{4}

\section{Results}

\subsection{Background and context}

Research results consist of descriptions and narrations/diagrams in response to open-ended questions. Responses were compared: between data sets (interviews/questionnaires/observations) and with the literature review. The comparative analysis identified specific themes, which were categorised and used to flag the data (electronic text and diagrams). Data was analysed according to the core research questions, discussed in next sections.

Research results indicate, at the time of the interviews/RFP:

- Interviewees' experience: two and half years' to twenty eight years' experience in banking/IT.

- Interviewees were involved in strategic and operational BI work. Strategic work typically being analysis, insight and BI project work. Operational work being data collection, processing and maintenance.

- Two of the eight RFP respondents are local vendors with 50 people or less in their employ, established for five or fewer years. The remaining six RFP respondents operate locally and internationally, each with a surplus of 1,000 employees and over 21 years' BI experience.

\subsection{BI's core challenges}

FB's business intelligence core challenges were identified chiefly through interviews and observations, though RFP responses also provided input. Direct and indirect questions were asked during interviews to identify challenges and compare FB's challenges to those identified in the literature. The case study revealed that key challenges identified in the literature were also experienced at FB, to a greater or lesser extent. Additional challenges that emerged in the case study are indicated in Table 3 below, suffixed with $\mathrm{O}$, I or $\mathrm{V}$ for Observed, Interviewee or Vendor. The case study also highlighted that FB's and its vendors' attempts to overcome BI's challenges are neither aimed directly at BI's challenges, nor are they consistently successful: there is a need for a new approach.

\subsection{How BI is understood: perceptions of $B I$ and beliefs about $B I$}

The task of gaining insight on BI perceptions was approached by determining how BI is defined and contextualised. All respondents (interviewees and RFP respondents) were asked to define BI, describe the BI process, explain the purpose of $\mathrm{BI}$ and describe its components.

The results obtained were fairly congruent with the literature review. Technology, process and product perceptions emerged clearly but not that of BI as a capability or a department. The interviewees' dominating perception is that $\mathrm{BI}$ is a product, while only one vendor defined BI in this way. Vendors defined BI predominantly as a technology (63 per cent), with limited definitions of BI as a process and technology (1) and as a process (1).

Beliefs that emerged in the interviews, through observation and those inferenced through the RFP responses are indicated in Table 3.

\section{5}

\section{Discussion}

\subsection{Literature review and case study findings}

Key findings are summarised below in Table 3. Typical beliefs are linked to challenges and G-D logic characteristics that can be observed in the belief/challenge. All are categorised according to whether the principal focus is technology, process, product or capability.

Examining Table 3, it can be seen that G-D logic characteristics are inherent in the way BI is perceived and that they can be linked to BI challenges, specifically within categories of use and data. It is therefore proposed that a shift is made from G-D to S-D Logic as an opportunity to explore new avenues to overcome BI's prevailing challenges. 


\section{Table 3}

Bl's perceptions resulting in challenges due to an underlying G-D logic

\begin{tabular}{|c|c|c|}
\hline & Associated challenge & Inherent G-D logic characteristic \\
\hline \multicolumn{3}{|c|}{ Technology perception } \\
\hline $\begin{array}{l}\text { Collect/process great volumes of data } \\
\text { because technological capability } \\
\text { exists (Willcocks \& Whitely, 2009) } \\
(I, O)\end{array}$ & $\begin{array}{l}\text { Data overload leads to low use of } \mathrm{BI}(\mathrm{I}, \\
\mathrm{O}, \mathrm{V}) \\
\text { Individuals cannot process massive } \\
\text { amounts of data and information at } \\
\text { speed at which technology generates } \\
\text { it, resulting in "data deluge" or } \\
\text { "analysis paralysis" (LaValle et al., } \\
\text { 2010; Davis et al., 2011) }\end{array}$ & $\begin{array}{l}\text { Focus is on means and production: a } \\
\text { manufacturing mindset (Gummesson, 1995) }\end{array}$ \\
\hline $\begin{array}{l}\text { BI use measured by number of } \\
\text { licences sold (Pendse, 2009) (O) }\end{array}$ & $\begin{array}{l}\text { Inflated report of } \mathrm{BI} \text { use leads to } \\
\text { further unused purchases (white } \\
\text { elephants) (O) } \\
\text { It's often assumed } \mathrm{BI} \text { is used simply } \\
\text { because IT solution is implemented } \\
\text { (Ackerman, 2005; Atre, 2011) }\end{array}$ & $\begin{array}{l}\text { Vendors see value in exchange, not value in } \\
\text { use (Chesbrough \& Spohrer, 2006) }\end{array}$ \\
\hline $\begin{array}{l}\text { Decision-making will automatically be } \\
\text { enabled through purchase of BI IT } \\
\text { solution (Ackerman \& Wickens, 2001) } \\
\text { (O) }\end{array}$ & $\begin{array}{l}\text { Human decision-making processes } \\
\text { neglected in favour of implementing } \\
\text { BI/IT solution: unwilling/unskilled } \\
\text { decision-makers (I, O, V) } \\
\text { Typical user is trained only on IT } \\
\text { solution while they don't know how to } \\
\text { ask the right questions or make } \\
\text { correct assumptions to use } \mathrm{BI} \\
\text { effectively (Hopkins et al., 2010) }\end{array}$ & $\begin{array}{l}\text { Value can be embedded in goods } \\
\text { (Gummesson,1998). Value can be } \\
\text { determined by provider alone (Spohrer et al., } \\
2008 \text { ) }\end{array}$ \\
\hline \multicolumn{3}{|c|}{ Process perception } \\
\hline $\begin{array}{l}\text { The } \mathrm{BI} \text { process is completed with the } \\
\text { output of a BI product }(I, O, V) \text {. } \\
\text { Advanced feature-rich products are } \\
\text { the key to competitiveness (Pendse, } \\
2009)(V)\end{array}$ & $\begin{array}{l}\text { Assume automatic use of BI solution } \\
\text { upon implementation. Thus, minimal } \\
\text { effort to ensure use after support } \\
\text { period (thus low use). Neglect of } \\
\text { human decision-making (I, O, V) } \\
\text { Users are often intimidated by BI } \\
\text { system features or don't understand } \\
\text { data (structures/organisation) imposed } \\
\text { by BI solution designers (LaValle et } \\
\text { al., 2010; Willcocks \& Whitely, 2009; } \\
\text { Pentaho, 2011) }\end{array}$ & $\begin{array}{l}\text { Production seen as end of value chain } \\
\text { (Vargo \& Lusch, 2008). Focus on the } \\
\text { tangible (Gummesson, 1995). } \\
\text { Activities/entities not equally acknowledged } \\
\text { (Lusch \& Vargo, 2005) }\end{array}$ \\
\hline $\begin{array}{l}\mathrm{BI} \text { is a repeatable, automated } \\
\text { process }(I, O, V)\end{array}$ & $\begin{array}{l}\text { More time spent on automation } \\
\text { activities than on human decision- } \\
\text { making. Data overload and } \\
\text { unproductive } \mathrm{BI} \text { effort }(I, O, V) \\
\\
\mathrm{BI} \text { effort is unproductive as user } \\
\text { experience is disorienting, frustrating, } \\
\text { complicated and time-consuming } \\
\text { (Atre, 2011; Popovič, Turk \& Jaklič, } \\
\text { 2010; Pentaho, 2011) (LR) }\end{array}$ & $\begin{array}{l}\text { Focus is on the means, production and } \\
\text { producer (Vargo \& Lusch, 2008) }\end{array}$ \\
\hline $\begin{array}{l}\mathrm{BI} \text { department is producer and } \\
\text { decision-maker is consumer OR } \mathrm{BI} \\
\text { vendor is producer and } \mathrm{BI} \text { department } \\
\text { consumer-i.e. separation, roles are } \\
\text { never switched }(I, O, V)\end{array}$ & $\begin{array}{l}\text { Separation leads to us versus them } \\
\text { attitude. Vendor and user don't } \\
\text { typically meet. BI decisions made } \\
\text { sans business. BI product handed } \\
\text { over unsuccessfully (I, O, V) } \\
\text { BI users often have business focus } \\
\text { while BI solution development has IT } \\
\text { focus (Atre, 2011; Popovič et al., } \\
2010 \text { ) }\end{array}$ & $\begin{array}{l}\text { Producer/consumer separated and do not } \\
\text { switch roles (Vargo \& Lusch, 2008), thereby } \\
\text { losing out on contextual knowledge of each } \\
\text { other's environments (Chesbrough \& } \\
\text { Spohrer, 2006) }\end{array}$ \\
\hline \multicolumn{3}{|c|}{ Product perception } \\
\hline $\begin{array}{l}\mathrm{BI} \text { product, representing the outcome } \\
\text { of the } \mathrm{BI} \text { process, is the focus of the } \\
\text { exchange. Existence of a } \mathrm{BI} \text { product } \\
\text { is a solution }(\mathrm{O})\end{array}$ & $\begin{array}{l}\text { Human decision-making processes } \\
\text { neglected, leads to low } \mathrm{Bl} \text { use due to } \\
\mathrm{BI} \text { users unskilled in decision-making } \\
\text { processes/use of } \mathrm{BI} \text { solution(O) }\end{array}$ & $\begin{array}{l}\text { Goods exchanged for money, rather than } \\
\text { services for services (Lusch \& Vargo, 2006). } \\
\text { Value in exchange (not in use) (Chesbrough } \\
\text { \& Spohrer, 2006) }\end{array}$ \\
\hline
\end{tabular}




\begin{tabular}{|c|c|c|}
\hline & Associated challenge & Inherent G-D logic characteristic \\
\hline & $\begin{array}{l}\text { Dominant focus on data processing } \\
\text { reduces time/capacity for use } \\
\text { (Popovič et al., 2010; LaValle et al., } \\
\text { 2010) }\end{array}$ & \\
\hline $\begin{array}{l}\text { If the } \mathrm{BI} \text { product (e.g. a report/data) } \\
\text { exists, it will automatically be used } \\
\text { instead of intuition/experience alone } \\
\text { (Davenport, Cohen \& Jacobson, } \\
\text { 2005) (O) }\end{array}$ & $\begin{array}{l}\text { Users experience frustration using } \mathrm{BI} \\
\text { product imposed in their world. } \\
\text { Product may not fit in user world: } \mathrm{BI} \text { is } \\
\text { context dependent (O) } \\
\text { Providing } \mathrm{BI} \text { that is relevant, timeous } \\
\text { and valued by the user is difficult } \\
\text { (Coulonval et al., 2010) }\end{array}$ & $\begin{array}{l}\text { Provider determines value. Product created } \\
\text { with a customer in mind (Spohrer et al., } \\
2008) . \text { Operand resources are not enhanced } \\
\text { by consumer after exchange (value } \\
\text { destroyed in use) }\end{array}$ \\
\hline $\begin{array}{l}\text { BI product such as knowledge or } \\
\text { intelligence is automatically available } \\
\text { through the outcome of the } \mathrm{BI} \text { process } \\
(I, O, V)\end{array}$ & $\begin{array}{l}\text { Process to turn } \mathrm{BI} \text { product into } \\
\text { intelligence/knowledge for decision- } \\
\text { maker neglected. Lower } \mathrm{BI} \text { use due to } \\
\text { misalignment. } \mathrm{BI} \text { is context dependent } \\
\text { (O) } \\
\text { A gap exists between the BI system } \\
\text { and human decision making that BI } \\
\text { system doesn't close (Todd, 2009; } \\
\text { Green, 2007) }\end{array}$ & $\begin{array}{l}\text { Value can be determined upfront and } \\
\text { embedded during production by provider } \\
\text { (Gummesson, 1998). Value is not personal, } \\
\text { experiential, contextual or meaning-laden } \\
\text { (Vargo, 2009) }\end{array}$ \\
\hline \multicolumn{3}{|c|}{ Capability perception } \\
\hline $\begin{array}{l}\text { BI users have the capability/know } \\
\text { what to ask and what assumptions to } \\
\text { make when using BI tools (Green, } \\
2007)(I, O)\end{array}$ & $\begin{array}{l}\text { Frustration leads to low } \mathrm{BI} \text { use, } \mathrm{BI} \\
\text { credibility diminishes due to "wrong" } \\
\text { answers (data often blamed and } \\
\text { reworked) (Hopkins et al., 2010) }(I, O)\end{array}$ & $\begin{array}{l}\text { Value is obtained during exchange, therefore } \\
\text { product's use is not provider's priority } \\
\text { (Chesbrough \& Spohrer, 2006) }\end{array}$ \\
\hline $\begin{array}{l}\text { The average business user has the } \\
\text { know-how or time to use BI tools } \\
\text { (LaValle et al., 2010) (O) }\end{array}$ & $\begin{array}{l}\text { BI use is low, } \mathrm{BI} \text { competence often } \\
\text { lacking, misalignment between BI-IT- } \\
\text { business when } \mathrm{BI} \text { or IT thinks } \\
\text { business should know technology }(I, O) \\
\\
\text { It's difficult to change from making } \\
\text { decisions based on intuition/personal } \\
\text { knowledge to making them on BI facts } \\
\text { (LaValle, 2010) }\end{array}$ & $\begin{array}{l}\text { Value can be determined upfront by provider: } \\
\text { it is not personal, experiential, contextual or } \\
\text { meaning-laden (Vargo, 2009) and can be } \\
\text { embedded in product during production } \\
\text { (Gummesson, 1998) }\end{array}$ \\
\hline $\begin{array}{l}\text { The ultimate goal of } \mathrm{BI} \text { is the } \\
\text { capability to make decisions, delivery } \\
\text { of a BI product enables this capability } \\
(\mathrm{O}, \mathrm{V})\end{array}$ & $\begin{array}{l}\text { Mere product implementation is } \\
\text { insufficient to meet business } \\
\text { requirements, resulting in low use. } \\
\text { Skills to use product undeveloped } \\
(I, O, V) \\
\text { Training often focuses narrowly on } \\
\text { how to use BI system, not on how to } \\
\text { leverage underlying data (HP, 2009) }\end{array}$ & $\begin{array}{l}\text { Value determined upfront during production } \\
\text { by provider alone (Spohrer et al., 2008). } \\
\text { Value can be created by provider or } \\
\text { consumer alone (Maglio, Srinivasan, Kreulen } \\
\text { \& Spohrer, 2006) }\end{array}$ \\
\hline
\end{tabular}

Key: O, I, V, LR: sourced from Observation, Interviews or Vendor responses or referenced if from the Literature review

\subsection{Recommendation: A shift to S-D logic}

By shifting the perception of BI and the beliefs about BI to be grounded in S-D rather than GD logic, significant progress can be made towards overcoming many of BI's prevailing challenges. While a lengthy discussion of this is justified, the scope of this paper extends only to highlight the potential of S-D logic. Therefore only a few examples are provided herein, leaving potential for further research in this direction.

Consider the following examples of potential benefits of applying S-D logic:

- By shifting the focus from value-in- exchange to value-in-use (Vargo \& Lusch, 2008), BI providers may consider allocating more capacity to activities involving BI use than BI production. E.g. assisting customers to understand and use the BI delivered, focusing on human decision-making rather than just implementation of a BI product/ solution. This can potentially also alleviate challenges experienced by BI customers in terms of data overload. BI providers may also measure use differently and not according to the number of licences sold, thereby getting a more accurate view that facilitates improvements in use of BI, where the BI customer needs to actively participate to co-create value or benefit. 
- By shifting from a focus on the means, production and producer (Vargo \& Lusch, 2008) to a balanced focus on both production and use, less time can be spent on automation activities versus human decision-making activities. This can also bring the BI customer and BI provider together: both become responsible to cocreate value and use the BI that is delivered. This shift entails that the BI provider realises he/she cannot determine the value upfront (Gummesson, 1998) but has to work closely with the BI customer to realise benefit and cannot impose a BI solution on a BI customer. Simultaneously, the BI customer realises that participation is necessary, he/she is no longer the "passive recipient" (Vargo \& Lusch, 2008).

\section{6}

\section{Conclusion}

This paper starts by establishing that although expectations of BI success are high, there are many failures and challenges reported on for $\mathrm{BI}$ and that - due to largely unsuccessful results of existing approaches - a new approach is needed to overcome BI challenges. As G-D and S-D logic are used as lenses through which to examine $\mathrm{BI}$ in this research, an explanation of G-D and S-D logic is then provided. This is followed by an explanation of BI as an exchange process, where it is placed in context of S-D logic. With this supporting foundation established, the paper then answers the research questions based on findings from the literature review and case study.

"How is BI understood/perceived?" is answered in two ways. Firstly, through identification of four core perceptions of BI, namely: BI as a technology, process, product and/or capability. Secondly, through identification of beliefs held about BI - these provide additional insight into the understanding of BI and can be seen as the result of perceiving BI in a specific way. In turn, the understanding of $\mathrm{BI}$ as one or more perception linked to specific beliefs, results in the occurrence of specific BI challenges or opportunities (Heylighen, 2000).

"Is the way BI is understood grounded in G-D or S-D logic?" and "Can BI challenges be linked to G-D logic or the way BI is understood?" are both answered through the linkage of G-D logic characteristics to BI perceptions and beliefs as well as BI challenges, tabulated in Table 3.

This paper concludes by recommending a shift to S-D logic, briefly describing examples of the benefit that this will bring about for BI in terms of overcoming challenges that can be linked to an inherent G-D logic in BI.

This research provides a necessary first step of identifying the inherent G-D logic in BI. It is the intention of the authors to release further papers detailing how S-D logic can be applied to BI and how the shift from G-D to S-D logic can be made. In addition, this research focuses on BI challenges. Future research is therefore suggested to examine BI successes in terms of S-D logic in a similar way or using this research as a basis. Finally, as this paper focuses on BI challenges in categories of "use" and "data", the aim is to expand this to other challenge categories identified - i.e. integration, alignment, personnel and skills, and sponsorship.

\section{References}

ACKERMAN, M. 2005. Processes for unlocking actionable business intelligence in SA banking institutions. University of Pretoria. (Master's dissertation. The University of Pretoria.).

ACKERMAN, M. \& WICKENS, P. 2001. Customer intelligence: Achieving effective CRM for competitive advantage. London: Lafferty Publications.

ATRE, S. 2011. Who in the world .... series. Available at: http://www.atre.com [accessed 2011-08-05]. BERSTEIN, A., GROSOF, B. \& PROVOST, F. 2011. Business intelligence: The next frontier for information systems research? Available at: www.mit. edu/bgrosof/ paps/wits01 [accessed 2011-08-19]. CHANDLER, J.D, \& VARGO, S.L. 2011. Contextualization and value-in-context: How context frames exchange. Marketing Theory, 11(1):35-49.

CHESBROUGH, H. \& SPOHRER, J. 2006. A research manifesto for services science. Communications of the ACM, July:35-40. 
CHUAH, M. \& WONG, K. 2011. A review of business intelligence and its maturity models. African Journal of Business Management, (5:9):3424-2428.

CLAVIER, P.R. 2012, A service-dominant logic approach to business intelligence, PhD thesis, University of Pretoria, Pretoria. Available at: < http://upetd.up.ac.za/thesis/available/etd-04302013-142906/ > D13/4/430 [accessed 2014-02-25].

CLAVIER, P.R., LOTRIET, H.H. \& VAN LOGGERENBERG, J.J. 2012. Business intelligence challenges in the context of goods- and service-dominant logic. pp.4138-4147, 2012 45th Hawaii International Conference on System Sciences, 2012.

COULONVAL, J.F., CURITZ, P \& FINKELSTEIN, M. 2010. Does your BI tell you the whole story? KPMG Performance and Technology Advisory, 2010:1-20.

DAVENPORT, T.H., COHEN, D. \& JACOBSON, A. 2005. Competing on analytics. BABSON Education. May 2005.

DAVIS, M.M., SPOHRER, J.C. and MAGLIO, P.P. 2011. Guest editorial: How technology is changing the design and delivery of services. Operations Management Research, 4:1-5.

DUAN, L. \& DA XU, L. 2012. Business intelligence for enterprise systems. IEEE Transactions on Industrial Informatics, 8(3):679-687.

EDVARDSSON, B., NG, G., ZHI MIN, C., FIRTH, R. \& Yi, D. 2011. Does service-dominant design result in a better service system? Journal of Service Management, 22(4):540-556.

GREEN, A. 2007. Business information - a natural path to business intelligence: Knowing what to capture. The Journal of Information and Knowledge Management Systems:18-23.

GUMMESSON, E. 1995. Relationship marketing: its role in the service economy. In: Understanding service management. William J. Glynn and James G. Barnes (eds.) New York: John Wiley \& Sons:244-268.

GUMMESSON, E. 1998. Implementation requires a relationship marketing paradigm. Journal of the Academy of Marketing Science, 26(Summer):242-249.

HENNING, E., VAN RENSBURG, W. \& SMIT, B. 2004. Finding your way in qualitative research. Pretoria: Van Schaik.

HERSCHEL, R.T. 2011. Marketing business intelligence. Available at: http://www.b-eye-network.com [accessed 2011-06-14].

HEYLIGHEN, F. 2000. What is a worldview? Available at: http://pcp.vub.ac.be/WORLVIEW.html [accessed 2011-06-10].

HOČEVAR B. \& JAKLIČ, J. 2010. Accessing benefits of business intelligence systems - A case study. Management:87-119.

HOPKINS, M.S., LAVALLE, S., BALBONI, F., KRUSCHWITZ, N. \& SHOCKLEY, R. 2010. 10 Insights: a first look at the new intelligent enterprise survey on winning with data. MIT Sloan Management Review, 52(1):22-32.

HORNBY, A.S. 2005. Oxford advanced learner's dictionary: international student's edition. (7th ed.) University of Oxford: Oxford University Press.

HP. 2009. Building the Business Intelligence competency centre: business white paper. Available at: www.hp.com/services/bi [accessed 2011-09-15].

KOWALKOWSKI, C. \& BALLANTYNE, D. 2009. Relationship value through the lens of the servicedominant logic. 17th International Colloquium in Relationship Marketing (Maastricht, The Netherlands).

LAVALLE S., HOPKINS M.S., LESSER E., SHOCKLEY R. \& KRUSCHWITZ, N. 2010. Analytics: The new path to value. MIT Sloan Review and IBM Institute. Available at: http://sloanreview.mit.edu [accessed 2010-11-29]

LUSCH, R.F. \& VARGO, S.L. 2005. The service-dominant mindset. Service Science Management and Engineering (SSME):89-96.

LUSCH, R.F. \& VARGO, S.L. 2006. The service-dominant logic of marketing. Dialog, debate, and directions. M.E. Sharpe, Inc. New York. pp. xvii.

LUSCH, R.F. \& WEBSTER, E. 2011. A stakeholder-unifying, cocreation philosophy for marketing. Journal of Macromarketing, 31(2):129-134.

LUSCH, R.F., VARGO, S.L. \& WESSELS, G. 2008. Toward a conceptual foundation for service science: contributions from service-dominant logic. IBM Systems Journal, 47(1):5-13. 
MAGLIO, P.P., SRINIVASAN, S., KREULEN, J.T. \& SPOHRER, J. 2006. Service systems, service scientists, SSME, and innovation Communications of the ACM, 49(7):81-85.

MAGLIO, P.P. \& SPOHRER, J.C. 2008. Fundamentals of service science. Journal of the Academy of Marketing Science, 36:18-20.

MAGLIO, P.P. \& SPOHRER, J., 2013. A service science perspective on business model innovation. Available at: http://dx.doi.org/10.1016/j.indmarman [accessed 2013-06-13].

PAYNE, A. \& FROW, P. 2005. A strategic framework for customer relationship management. The Journal of Marketing, 69(4):167-176.

PENDSE, N. 2009. Busting the BI myths. BI survey 7 results. DM Review, July 2008:12-14.

PENTAHO. 2011. Official Pentaho Cognos website. Available at: www.pentaho.com [accessed 2011-09-14].

PIRTTIMÄKI, V.H. 2007. Conceptual analysis of business intelligence. The South African Journal of Information Management, June 2007:1-17.

POPOVIČ, A., TURK, T. \& JAKLIČ, J. 2010. Conceptual model of business value of Business Intelligence systems. Management, 15(1):5-30.

RANDALL, W.S. 2007. An empirical examination of service-dominant logic: the theory of the network. University of north Texas (Doctor of philosophy.)

RICHARDSON, SCHLEGEL, HOSTMANN, MCMURCHY, 2009. Magic quadrant for business intelligence platforms 2008. Available at: http://www.gartner.com/it/strategic/G00154227 [accessed 2009-01-21].

TODD, G. 2009. Winning performance analytic strategies. Information Management, July/August 2009: 35-36.

SCHULZ, M. \& GNOTH, J. 2008. Understanding the service-dominant (S-D) logic from within the firm. Otago Forum 2, Academic Papers:127-138.

SPOHRER, M. TANNIRU, \& H. JIANNAN WANG. 2008. Communications of the Association of Information Systems, 22, art. 22:413-428.

VANMARE, J. 2006. The benefits of implementing business intelligence solutions in a South African banking institution. University of Pretoria. (MBA Dissertation, University of Pretoria.).

VARGO, S.L. 2009. Service-dominant logic: An introduction. Symposium on Service-Dominant Logic. University of Bayreuth, 10 June 2009. Available at: www.sdlogic.net/presentations.html [accessed 2012-05-23].

VARGO, S.L. 2011. On marketing theory and service-dominant logic: Connecting some dots. Marketing Theory, 11(1):3-8.

VARGO, S.L. \& LUSCH, R.F. 2004a. Evolving to a new dominant logic for marketing. Journal of Marketing, 68(1):1-17.

VARGO, S.L \& LUSCH, R.F. 2004b. The four service marketing myths: remnants of a goods-based manufacturing model. Journal of Service Research, 6(4):324.

VARGO S.L. \& LUSCH, R.F. 2008. Why service? Journal of the Academy of Marketing Science:25-38.

VARGO, S.L. \& LUSCH, R.F. 2006. Service-dominant logic: what it is, what it is not, what it might be. In The service-dominant logic of marketing. Dialog, debate, and directions. R.F. Lusch and S.L. Vargo (eds.), M.E. Sharpe, Inc.: New York.

VOM BROCKE, J., SIMONS, A., NIEHAVES, B., RIEMER, K., CLEVEN, A. \& PLATTFAUT, R. 2009. Reconstructing the giant: On the importance of rigour in documenting the literature search process. In: Proceedings of the European Conference on Information Systems. 2009:2206-2217.

WEBER, J. \& WATSON, R.T. 2002. Analyzing the past to prepare for the future: writing a literature review. MIS Quarterly, 26(2):xiii-xxiii.

WORLD BANK. 2013. Growth of the service sector. Available at: http://www.worldbank.org [accessed 2013-06-12].

WILLCOCKS, L. \& WHITELY, E.A. 2009. Developing the Information and knowledge agenda in information systems: Insights from philosophy. The Information Society:190-197.

WILLIAMS, J. \& AITKEN, R. 2011. The service-dominant logic of marketing and marketing ethics. Journal of Business Ethics. Available at: http://www.springerlink.com/index/ 10.1007/s10551-011-0823-z [accessed 2011-07-27]. 